\title{
What Trouble I Have Seen
}





\section{What Trouble I Have Seen}

$A$ History of Violence against Wives

\section{David Peterson del Mar}

\section{Harvard University Press}

Cambridge, Massachusetts London, England 
Copyright $\odot 1996$ by the President and Fellows of Harvard College All rights reserved

Printed in the United States of America

Second printing, 1998

First Harvard University Press paperback edition, 1998

Library of Congress Cataloging-in-Publication Data

Peterson del Mar, David, 1957-

What trouble I have seen : a history of violence against wives /

David Peterson del Mar.

p. $\mathrm{cm}$.

Includes bibliographical references ( $\mathrm{p}$. ) and index.

ISBN 0-674-95076-3 (cloth)

ISBN 0-674-95078-X (pbk.)

1. Wife abuse-Oregon-History. I. Title.

HV6626.22.07P47 1996

$362.82^{\prime} 92^{\prime} 09795-\mathrm{dc} 20 \quad 95-46974$ 
For those whose troubles will never be told 
